\title{
Gender and Reparations: Seeking Transformative Justice
}

Dr Emily Jones*

\section{A. Introduction}

Mass violations are gendered; from the ways in which harms are experienced by all subjects in gendered ways to how they are then understood or silenced in gendered ways. Feminist scholars and activists have critiqued the framing and granting of reparations, arguing that classical forms of compensation and restitution cannot reflect women's experiences. This is, in part, due to the specific harms women suffer as well as the fact that many of the harms women face occur because of preexisting inequalities. Providing restitution for the individual harm but not addressing the structures of inequality which fostered or caused the harm means returning women to a position of discrimination and inequality and therefore, a situation in which women's rights are still being violated. Thus, the challenge is how to repair victims as equal rights holders given the fact that some groups were not equal rights holders in the first place. Following this line of argument, restitution as a form of reparation risks not addressing core human rights concerns. While reparations and broader human rights adjudication work largely to address individual and familiar harms, there is also a need to balance these harms further with the need for societal change.

In response to concerns around often returning people to situations of inequality through the way reparations are currently applied, there have been multiple calls for and attempts to implement more transformative forms of reparations, i.e. reparations which seek to address and subvert preexisting unequal and discriminatory structures. Section two of this chapter outlines some of these responses, focusing on transformative reparations both as an essential framing of reparations from a

\footnotetext{
${ }^{*}$ Lecturer in Law, University of Essex. I would like to thank Carla Ferstman and Dianne Otto for their insights on this chapter. Much of this chapter was completed while I was undertaking a Kathleen Fitzpatrick Visiting Fellowship at the Laureate Program in International Law at Melbourne Law School. I would like to thank Anne Orford for this opportunity. All errors remain my own.
} 
gender perspective as well as an area in which further gender analysis could be pursued to great gain. However, since transformative reparations are largely undefined, how and whether such reparations have been taken up, or not, depends on one's perspective on what transformative reparations exactly entail. Section three therefore draws on feminist work as a way through which to provide an analysis of what transformative reparations could and have included. I then go on, in section four, to analyse some specific examples of reparations that have been used to challenge pre-existing structural inequalities, focusing on the Cotton Fields judgment at the Inter-American Court of Human Rights (IACtHR), and outlining the gender literature on reparations programmes. I argue that further and more radical transformative reparations are needed. Such reparations, it is posed, are possibly best implemented through guarantees of non-repetition.

Drawing on the examples given in sections three and four, section five outlines some possible ways in which gender-just transformative reparations can be developed further. One way that transformative reparations could be and to some extent have been applied is through communal reparations such as education, training and housing programmes with such programmes seeking to challenge and change oppressive structures in society. I argue that there is a need for reparations in these forms to be applied more often and their reach extended both in terms of what they offer and who is included. The need for a greater recognition of the currently often marginalised framework of economic and social rights is also noted, arguing for the further integration of these rights into reparations frameworks. I then go on to note the need for intersectional analyses within the field of transformative reparations. Such analyses are required to ensure that transformative reparations can properly understand and take full account of the various harms many people face due to discrimination, structural inequality and oppression.

The final section of this chapter analyses the limits of the field of gender and transformative reparations by drawing on other critical approaches to international law which have been little applied to this area, including postcolonial feminist analyses. Noting that reparations are a secondarily applied 
right granted in response to a primary rights violation, the limits of the human rights framework in being able to provide transformative justice is questioned. I conclude by arguing that further critical engagement is essential both in order to frame reparations in truly transformative ways as well as to understand the limits of the transformative project and, subsequently, of human rights law, in being able to provide transformation.

\section{B. Gender and Reparations}

The right to 'adequate, effective and prompt' ${ }^{1}$ remedies and reparations for gross violations of international human rights law (IHRL) and serious violations of international humanitarian law (IHL) is recognised as a human right under international law. ${ }^{2}$ Reparations are broadly understood as measures adopted to redress the various harms suffered as a consequence resulting from certain crimes or of a breach of state responsibility. While reparations are generally understood under public international law as aiming at providing restitution, ${ }^{3}$ most human rights bodies have focused on compensation as the means of providing just satisfaction. This approach follows the recognition that restitution, the idea of putting the person back in the situation of pre-violation, is difficult - if not impossible - to achieve. Compensation is thus used as a form of reparation when restitution is not possible. However, there have been moves in recent years towards understanding and providing

\footnotetext{
${ }^{1}$ UN General Assembly, 'Basic Principles and Guidelines on the Right to a Remedy and Reparation for Victims of Gross Violations of International Human Rights Law and Serious Violations of International Humanitarian Law,' A/RES/60/147, 21 March 2006, Article 15.

${ }^{2}$ See, for example, Basic Principles and Guidelines, ibid; 'Universal Declaration of Human Rights (UDHR),' 217 A (III) 10 December 1946, Article 8; 'International Covenant on Civil and Political Rights,' UN Treaty Series Vol. 999, 16 December 1966, Article 2; 'International Convention on the Elimination of All Forms of Racial Discrimination (CERD),' UN Treaty Series Vol. 660, 21 December 1965, Article 6; 'Convention Against Torture and Other Cruel, Inhumane or Degrading Treatment or Punishment,' UN Treaty Series Vol. 1465, 10 December 1984, Article 14; International Conferences (The Hague), 'Hague Convention (IV) Respecting the Law and Customs of War on Land and in its Annex: Regulations Concerning the Law and Customs of War on Land,' 18 October 1907, Article 3; International Committee of the Red Cross, 'Protocol Additional to the Geneva Conventions of 12 August 1949, and relating to the Protection of Victims of International Armed Conflicts (Protocol I),' 1125 UNTS 3, 8 June 1977, Article 91; 'Rome Statute of the International Criminal Court,' ISBN No. 92-9227-227-6, 17 July 1998 (last amended 2010), Articles 68 and 75.

${ }^{3}$ Factory at Chorzów, Germany v Poland, Jurisdiction, Judgment, PCIJ Series A No 9, ICGJ 247 (PCIJ 1927), 26 July 1927.
} 
reparations beyond compensation and even, as this section will show, beyond restitution, with many of the key proposals coming from feminist scholars and activists.

The 2005 Basic Principles and Guidelines on the Rights to Remedy and Reparation for Victims of Gross Violations of International Human Rights Law and Serious Violations of Internationals Humanitarian Law, ${ }^{4}$ also known as the van Boven Principles, marked a key moment in the realm of reparations. The Principles recognise the right to a remedy and reparation, and the corresponding duty of states under international law, in response to a gross violation of IHRL or a serious violation of IHL, ${ }^{5}$ garnering a much greater focus on reparations. Effective reparation constitutes, according to the Basic Principles and Guidelines, restitution, compensation, rehabilitation, satisfaction and guarantees of non-repetition, ${ }^{6}$ noting also that the Principles in both their 'application and interpretation,' must be non-discriminatory 'without exception.' ${ }^{7}$ While it is evident that these Basic Principles and Guidelines are foundational, it remains unclear what constitutes a gross violation of IHRL or a serious violation of IHL. ${ }^{8}$ Since the adoption of the resolution, there have been multiple debates on the definitional parameters of these "gross" and "serious" violations with, at best, rather conservative definitions being given around the "worst" forms of violation. ${ }^{9}$ In addition, gender and other intersecting identities and structural inequalities are not explicitly mentioned in the principles, despite the arguments of feminist scholars that hierarchising some harms as "worse" than others often prioritises the harms men face, leaving out the harms women are more likely to face. ${ }^{10}$

\footnotetext{
${ }^{4}$ Basic Principles and Guidelines' (n 2).

${ }^{5}$ Despite the noting of these obligations as core, they fall very much into the remit of soft law. However, the Basic Principles and Guidelines themselves state that this right to a remedy and reparations comes from core IHRL and IHL obligations (Para 4 under principle III). However, there remains a debate as to whether the Basic Principles and Guidelines enshrined the right to a remedy and reparation or whether that right ever really did exist, Tomuschat thus contrasting the van Boven Principles to what he defines as the similarly ambitious Articles on Responsibility of States for Internationally Wrongful Acts which, he notes, were created, in contrast to the van Boven Principles, based on a solid foundation of settled state practice. (See; Christian Tomuschat, 'Reparation in Favour of Individual Victims of Gross Violations of Human Rights and International Humanitarian Law,' in Marcelo Kohen (ed.), Promoting Justice, Human Rights and Conflict Resolution through International Law, (Leiden: Brill 2006) 569).

${ }^{6}$ Basic Principles and Guidelines (n 2), paras. 19-23.

${ }^{7}$ Ibid, para. 25.

${ }^{8}$ See the Chapter by Theo van Boven in this volume. He explains the background to the inclusion of these terms in the Basic Principles and Guidelines.

${ }^{9}$ Ibid.

${ }^{10}$ Hilary Charlesworth and Christine Chinkin, 'The Gender of Jus Cogens,' (1993) 15(1) Hum Rts Q 63.
} 
Feminists have, however, long shown the ways in which harm is experienced by men and women differently. ${ }^{11}$ For example, women are more likely to be subjected to sexual or reproductive violence or to forms of enslavement. ${ }^{12}$ In addition, these forms of violence come with specific longer term impacts such as social stigmatisation, sexually transmitted infections (STIs) and unwanted pregnancies. ${ }^{13}$ Women are also more likely than men to suffer from malnutrition and starvation during conflict. ${ }^{14}$ They are also more likely to be subject to internal displacement during both internal and international armed conflicts than men. ${ }^{15}$ To repair such harm therefore, requires an analysis which takes into account all of these gendered factors, including the different ways men and women experience the supposedly same harm differently due to pre-existing social and economic factors. ${ }^{16}$

Before 2005, when the van Boven Principles were drafted, gender-based reparations had received little international legal attention. Article 2 of the Convention on the Elimination of all Forms of Discrimination Against Women $(\mathrm{CEDAW})^{17}$ requires legal change to end discrimination against women in broad terms, while the Declaration on the Elimination of Violence against Women (DEVAW) provides a little more detail in Article 4(d) which provides that states have a duty to develop penal, civil, labour and admin sanctions to punish and redress violence against women (VAW). ${ }^{18}$ Thus, women's rights advocates were concerned first, that the van Boven Principles were not sufficient to

\footnotetext{
${ }^{11}$ It is impossible to cover the entire spectrum of gendered harms in this chapter. This is not the focus of this chapter. However, see, for a general overview, bringing together the opinions of various feminist international lawyers; Rebecca J. Cook, 'Women's International Human Rights Law: The Way Forward,' (1993) 15 Hum Rts Q 230. See also, on this theme, Charlesworth and Chinkin, ibid; Judith Gardham, 'Woman and the Law of Armed Conflict: Why the Silence?' (1997) 46(1) Intl \& Comp L Q 55.

${ }^{12}$ UN Human Rights Council, 'Report of the Special Rapporteur on violence against women, its causes and consequences,' A/HRC/14/22, 23 April 2010.

${ }^{13}$ For more on gender-based violence in conflict and post-conflict settings see, Rashida Manjoo and Calleigh McRaith, 'Gender-Based Violence and Justice in Conflict and Post-Conflict Areas,' (2011) 11 Cornell Intl L J 11.

${ }^{14}$ Gardham (n 11).

${ }^{15}$ UN Human Rights Council (n 12). For more on the gendered harms women face and then need for reparations, see, Margaret Urban Walker, 'Gender Violence in Focus: A Background for Gender Justice in Reparations,' in Ruth RubioMarín (ed), The Gender of Reparations: Unsettling Sexual Hierarchies while Redressing Human Rights Violations, (Cambridge: Cambridge University Press 2009) 18.

${ }^{16}$ UN Human Rights Council (n 12).

17 'Convention on the Elimination of All Forms of Discrimination against Women (CEDAW),' UN Treaty Series Vol. 1249, 18 December 1979, Article 2.

18 'Declaration on the Elimination of Violence Against Women (DEVAW),' A/RES/48/104, 20 December 1993, Article 4(d).
} 
address the reparations needs of women and girls and second, that the lack of focus on gender in these Principles and Guidelines would, once again, work to deeply gender their use and effect. Concerned that men remained the central subjects of reparations analysis, women's rights advocates and activists drafted the Nairobi Declaration on Women's and Girl's Right to a Remedy and Reparation in $2007 .{ }^{19}$ Written in response to the aforementioned van Boven Principles, this civil society initiative affirms the basic tenets of the Basic Principles and Guidelines before outlining a women's and girl's rights approach to reparations. The Declaration specifically focuses on implementing this approach with respect to victims of sexual violence, noting, for example, the need to ensure non-discrimination in the application of the right to a remedy and reparation through redressing gender-based violence, ${ }^{20}$ while also noting that the determination of who counts as a victim must also take into account women and girls' experiences. ${ }^{21}$ The Declaration not only calls for a more focused gender approach which pays attention to gender-based violence but, in addition, it seeks to move beyond stereotypical views of the roles of women and girls' in conflict, calling for the recognition of a wider range of gendered harms including, for example, the rights of girl soldiers who have been forced to join military groups. ${ }^{22}$ The Declaration also notes the need for reparations to drive post-conflict transformation of socio-cultural injustices and to tackle the political and structural inequalities that shape the lives of women and girls', noting that reintegration and restitution are not enough when the origins of violations of women's and girls' human rights often predate the conflict. ${ }^{23}$

The Declaration - which was preceded by multiple feminist interventions before it which have defined gender as an overarching hierarchical and oppressive social construct ${ }^{24}$ - also states that

\footnotetext{
19 'Nairobi Declaration on Women's and Girls' Right to Remedy and Reparation,' Nairobi, 22 May 2007. For more background on the principles see; Valérie Couillard, 'The Nairobi Declaration: Redefining Reparations for Women Victims of Sexual Violence,' (2007) 1 Intl J Transitional J 444.

${ }^{20}$ Nairobi Declaration, ibid.

${ }^{21}$ Ibid, para. 4.

22 Coalition on Women's Human Rights in Conflict Situations, 'Background Paper: Women's Right to Reparation,' available at http://www.womensrightscoalition.org/site/pdf/Eng_Reparation2_fin.pdf. (accessed 26 June 2019); Couillard (n 19), 449.

${ }^{23}$ Nairobi Declaration (n 19).

24 There are multiple perspectives, however, on how this works exactly, with MacKinnon, for example, seeing patriarchy as an overarching oppressive construct, so much so that women can never even hear their own voice because male structures
} 
'reparation must go above and beyond the immediate reasons and consequences of the crimes and violations; they must address structural inequalities than negatively shape women's and girls' lives. ${ }^{25}$ As noted by one of the driving organisations behind the Declaration, the Coalition on Women's Human Rights in Conflict Situations, this is because, while reparations may seek to erase the consequences of the illegal act, ${ }^{26}$ ' $[\mathrm{r}] \mathrm{e}$-establishing the conditions that existed prior to the violation would mean restoring the gender status quo... endorsing and perpetuating practises' which deprive women of their human rights. ${ }^{27}$ Thus, the Declaration calls for a transformative idea of justice which seeks to redress structural gender inequalities, moving from a reparative notion of reparations towards a transformative notion.

Since the Nairobi Declaration, the idea of transformative reparations has been taken up in numerous ways. In 2010, the UN Special Rapporteur on Violence Against Women, Manjoo, who had been involved in the drafting of the Declaration, used her thematic report to the Human Rights Council to focus on the topic of gender and reparations. She noted the need for reparations which are sensitive to addressing 'cross-cutting structural subordination and systematic marginalization, ${ }^{28}$ noting the specific issues with reparations which seek to redress the individual violation alone, noting how

govern all, leaving women with 'nothing to use but the twisted tools that have been shoved down our throats.' (Catharine A. MacKinnon, 'Feminism, Marxism, Method and the State: Toward a Feminist Jurisprudence,' (1983) 8(4) Signs, 635, 637. Crenshaw for example, however, has a different perspective, noting the ways in which gender and patriarchy intersect with different forms of oppression, such as race, to create differing forms of oppression. (Kimberlé Crenshaw, 'Mapping the Margins: Intersectionality, Identity Politics, and Violence Against Women of Color,' (1991) 43(6) Stanford L Rev, 1241). Butler, on the other hand, defines gender as a social construct which is overarching and oppressive but one which is also performative (Judith Butler, Gender Trouble, (New York: Routledge 2006)). Structural understandings of patriarchal oppression can be seen in the provisions of CEDAW, with Article 5(a) calling for states 'to modify the social and cultural patterns of conduct of men and women, with a view to achieving the elimination of prejudices...' ('CEDAW' (n 17), Article $5(\mathrm{a})$ ). In terms of the debates on reparations, in 2006, in her thematic report on the 'Standard of Due Diligence,' Yakin Ertürk, at the time the Special Rapporteur on Violence Against Women, noted that due diligence obligations remain underdeveloped and that 'very little information is available regarding State obligations to provide adequate reparations for acts of violence against women.' (See, 'Report of the UN Special Rapporteur on Violence against Women, its Causes and Consequences, Yakin Ertürk on Integration of the Human Rights of Women and the Gender Perspective: Violence against Women: The Due Diligence Standard as a Tool for the Elimination of Violence against Women,' UN Doc. E/CN.4/ 2006/61, 20 January 2006). The impact of Ertürk's report has been noted by Manjoo (See, Rashida Manjoo, 'Introduction: Reflections on the concept and implementation of transformative reparations,' (2017) 21(9) Intl J Hum Rts 1193, 1193). Ertürk's report is also directly mentioned in Manjoo's own 2010 report where she focused specifically on gender and reparations. (See, UN Human Rights Council (n 12)).

${ }^{25}$ Nairobi Declaration (n 19).

${ }^{26}$ Basic Principles and Guidelines (n 2).

${ }^{27}$ Coalition on Women's Human Rights in Conflict Situations (n 22).

${ }^{28}$ UN Human Rights Council (n 12). 
violence against women and girls (VAWG) often predates the conflict and highlighting the fact that acts of VAWG are part of and must be situated within a larger system structural hierarchy. ${ }^{29}$ As Manjoo notes, it is clear that the typical measure of redress which seek to return the victim to her situation before the violation may not always be appropriate for women and girls as such measures risk not addressing the structural causes behind the violence. ${ }^{30}$

Thus, as highlighted above, noting that restitution and even other forms of reparation such as compensation and symbolic reparations, risk returning women to a situation of inequality where their human rights are still being violated, many varying voices have called for transformative reparations in the name of gender justice. ${ }^{31}$ However, precisely what these transformative reparations could be and how they could be applied is still being debated. ${ }^{32}$ I now turn to outlining some of the forms of transformative gender reparations which have been put forward by scholars and practitioners, analysing them in turn. I will then use the following sections of this chapter to outline what I think transformative reparations can and should include.

\section{Transformative Gender Reparations}

One proposal for transformative reparations has been explained through compensation itself. Noting the limitations of typical forms of compensation for women, in that compensation does not challenge the situation of discrimination which fostered the harm, this proposal calls for compensation to be

\footnotetext{
${ }^{29}$ Ibid, para 31. See also, Anne Saris and Katherine Lofts, 'Reparation Programmes: A Gendered Perspective,' in Carla Ferstman et al. (eds), Reparations for Victims of Genocide, War Crimes and Crimes Against Humanity, (Leiden: Brill 2009) $79,87$.

${ }^{30}$ UN Human Rights Council (n 12), para. 32.

31 See, for example, Olga Jurasz, 'Reparations for Gendered Harm at the International Criminal Court: Towards Transformative and Gender-Just Reparations?' in Olga Jurasz and Solange Mouthaan (eds), Gender and War: International and Transitional Justice Perspectives, (Intersentia 2019) 235; Manjoo, 'Introduction' (n 24); UN Human Rights Council (n 12); Fionnuala D. Ní Aoláin, Catherine O'Rourke and Aisling Swaine, 'Transforming Reparations for Conflict-Related Sexual Violence: Principles and Practice,' (2015) 26 Harvard Hum Rts J 97; Ruth Rubio-Marín (ed), The Gender of Reparations: Unsettling Sexual Hierarchies while Redressing Human Rights Violations, (Cambridge: Cambridge University Press 2009); Saris and Lofts (n 29), 90; Nairobi Declaration (n 19); Ruth Rubio-Marín, What Happened to the Women? Gender and Reparations for Human Rights Violations, (Social Science Research Council 2006).

${ }^{32}$ See; Brianne McGonigle Leyh and Julie Fraser, 'Transformative Reparations: changing the game or more of the same?' (2019) 8(1) Cambridge Intl LJ 39; Margaret Urban Walker, 'Transformative Reparations? A Critical Look at a Current Trend in Thinking about Gender-Just Reparations,' (2016) 10(1) Intl J Transitional J 108.
} 
provided via means which can disrupt discriminatory structures. A key example of such a model in use can be seen in giving women access to microfinance as a means of compensation, seeking to promote women's agency while avoiding large payments which are often taken control of by male heads of household. ${ }^{33}$ Microfinance does seem like an innovative way to challenge traditional compensatory models. However, while providing shares in microfinance may seem transformative, such a project relies on a frame through which freedom and autonomy is seen as a something to be gained through participation in the free market. ${ }^{34}$ The linking of neoliberal ideologies to concepts of freedom and agency can hardly be called transformative in an era in which neoliberalism is one of the biggest causes of global inequalities. ${ }^{35}$ In addition, as Rao has noted, defining freedom and agency in terms of market participation leaves out a host of subjects from view who may not wish to or may not be able to participate in the market in this way. ${ }^{36}$

Other scholars have argued for a more gender sensitive use of restitution to promote structural change. For example, Nesiah et al. note how property restitution in some contexts has had a gendered impact in that such reparations often do not reach women because men largely hold the property. ${ }^{37}$ However, allocating property specifically to women could be one means of challenging gender norms, disrupting long-standing structures of gendered property laws. ${ }^{38}$ Such measures of proprietary and economic redistribution, however, must pay attention to gender imbalances, ${ }^{39}$ with large shifts in distribution risking further violence against women. Gradual changes thus seem more promising, yet

\footnotetext{
${ }^{33}$ For more on microfinance models, gender and reparations, see; Anita Bernstein, 'Tort Theory, Microfinance, and Gender Equality Convergent in Pecuniary Reparations,' in Ruth Rubio-Marín (ed), The Gender of Reparations: Unsettling Sexual Hierarchies while Redressing Human Rights Violations, (Cambridge: Cambridge University Press 2009) 291.

${ }^{34}$ Rahul Rao, 'Global Homocapitalism,' (2015) 194 Radical Philosophy 38.

35 Note that even the neoliberal institution, the International Monetary Fund (IMF) is now questioning whether neoliberalism has been 'oversold,' noting the vast inequalities created by neoliberalism over the past few decades. See, Jonathan D. Ostry et al, 'Neoliberalism: Oversold?' Finance and Development, 2016.

${ }^{36}$ Rao (n 34).

${ }^{37}$ Vasuki Nesiah et al., 'Truth Commissions and Gender: Principles, Policies, and Procedures,' (2006) International Center for Transitional Justice, 35.

${ }^{38}$ Ruth Rubio-Marín, 'The Gender of Reparations in Transitional Societies,' in Ruth Rubio-Marín (ed), The Gender of Reparations: Unsettling Sexual Hierarchies while Redressing Human Rights Violations, (Cambridge: Cambridge University Press 2009) 63, 105.

${ }^{39}$ Vasuki Nesiah et al. (n 37), 35.
} 
gradual changes come with their own risks, the primary one being that after initial efforts, changes may stop when there is less focus on the system of redistribution. Another concern with redistribution of property rights is that by-passing legal discrimination in one context does not mean legal discrimination will be dismantled throughout the entire legal system, limiting any transformative impact. $^{40}$

Symbolic reparations have also garnered more attention in recent years, with the Cotton Fields judgment (discussed further below), for example, ordering a monument to be built in the field where the victims' bodies were found. ${ }^{41}$ In addition, the Extraordinary Chambers in the Court of Cambodia (ECCC) offered reparations through forms such as art work (in part as the ECCC did not have the power to hold the state responsible for the crimes before the Chambers). ${ }^{42}$ While symbolic reparations have the potential to be extremely powerful, symbolising a longer term commitment to "never again," it is also key to note how symbols have multiple interpretations. Differing interpretations and the tensions interpretations may cause can be seen through the example of the ECCC awarding an art work by French-Cambodian artist Séra to a group of victims in Cambodia. Some of these victims took offence to the piece which was seen as problematic from a religious and cultural perspective. ${ }^{43}$ Symbolic reparations are thus clearly limited in that they can be interpreted in multiple ways by multiple different victims: victims are not a monolithic group. ${ }^{44}$ Apologies as a form of symbolic reparation may not pose quite the same concerns. ${ }^{45}$ However, as a group of victims in the Democratic Republic of the Congo (DRC) have argued, while symbolic reparations and public apologies are important, there is also a need to prioritise 'tangible benefits to address the concrete need of victims,'

\footnotetext{
${ }^{40}$ See; Rubio-Marín, 'Transitional Societies' (n 38), 105.

${ }^{41}$ González et al. ("Cotton Field") v. Mexico (Preliminary Objection, Merits, Reparations and Costs), IACtHR, Ser. C No 205, 16 November 2009.

${ }^{42}$ See, Maria Elander, Figuring Victims in International Criminal Justice: The Case of the Khmer Rouge Tribunal, (New York: Routledge 2018).

${ }^{43}$ See, ibid. The art work in question is on the cover of Elander's book.

44 This is one of the core arguments of Elander's book - that there is no one figure of the victim but multiple figures. See, ibid.

${ }^{45}$ See, Rubio-Marín, ‘Transitional Societies' (n 38).
} 
their suggestion being that apologies and symbolic reparations should be used when attached to more 'tangible' forms of reparation. ${ }^{46}$

Another form of transformative reparation which has been used, for example, in Chile in the 1990s, mixes rehabilitation and compensation. This is done, for example, via granting small pensions as opposed to lump sums (and thus seeking again to avoid the problem with male heads of households taking control of any compensation awarded) and mixing these reparations with other forms such as education opportunities and the provision of medical services including specifically gender sensitive medical services such as the provisions of reproductive health services. ${ }^{47}$ A similar form was used by the Truth and Reconciliation Commission in Sierra Leone in the early 2000s where provisions were made for physical and mental health, pensions and education programmes and where microcredit projects were also set up. ${ }^{48}$ Rubio-Marín has argued these mixed forms of reparation proved quite successful, ${ }^{49}$ and it does indeed seem that a more holistic application of reparations is bound to have more success in transforming and challenging inequalities in society. However, there are issues around resource provision and who these services are provided to. One way to resolve this would be to provide such reparations only to identified victims, this model being used in Rwanda. However, in Rwanda, this allocation of reparations divided communities further and this went against the overall aim of transitioning to peace. ${ }^{50}$ In addition, allocating reparations in this way is problematic due to the issues in defining who is a victim and thus who should benefit. Multiple problems in terms of access may prevent many people from coming forward to be identified as victims, such as financial restraints, ability to travel, shame and fear of societal repercussions (which gender, here, being a key determining

\footnotetext{
${ }^{46}$ UN Office of the High Commissioner for Human Rights, 'Report of the Panel on Remedies and Reparations for Victims of Sexual Violence in the Democratic Republic of Congo to the High Commissioner for Human Rights,' March 2011, para. 150.

${ }^{47}$ Rubio-Marín, ‘Transitional Societies’ (n 38), 111.

${ }^{48}$ Ibid, 90; Jamesina King, 'Gender and Reparations in Sierra Leone,' in Ruth Rubio-Marín, (ed) What Happened to the Women? Gender and Reparations for Human Rights Violations, (Social Science Research Council 2006) 266.

${ }^{49}$ Rubio-Marín, 'Transitional Societies' (n 38), 111.

${ }^{50}$ Ibid, 111; Heidy Rombouts, 'Women and Reparations in Rwanda: A Long Path to Travel,' in Ruth Rubio-Marín, (ed) What Happened to the Women? Gender and Reparations for Human Rights Violations, (Social Science Research Council 2006) 194, 228. See also, the Chapter by Felix Mukwiza Ndahinda in this volume.
} 
factor). ${ }^{51}$ To allocate resources only to identified or even supposedly identifiable victims means excluding many and thus, to be effective, such reparations need to be provided to all.

Given some of the reasons outlined above, many scholars and practitioners state that the most promising area in which to situate transformative reparations is within guarantees of non-repetition. ${ }^{52}$ This area is seen as promising because it triggers discussions about the underlying gendered structural causes of violence. ${ }^{53}$ In addition, guarantees of non-repetition offer a way through which to address the collective need, this avoiding some of the issues outlined above through allocating reparations only to identified victims, for example. Such reparations could be granted, therefore, to a whole category of victims without needing to individually identify these victims and could be used to challenge oppressive structures in society more broadly, moving beyond the individual harm by noting the collective context of discrimination which fostered the harms in the first place. ${ }^{54}$ While there has been quite a lot of discussion around the need for collective reparations,${ }^{55}$ despite an increased interest in exploring this area over the past few decades, there is very little discussion (at least within the mainstream of the debate) on how such frames may work alongside gender-just reparations. ${ }^{56}$

Of course, structurally transformative reparations through guarantees of non-repetition come with their own host of problems. First, and as this chapter will come on to discuss in more detail, while many scholars have called for such reparations for women, there is a need to recognise that oppression is intersectional and that, for example, indigenous or differently abled women may be treated differently to other women. This understanding is needed to be able to fully address the multiple oppressive structures of society. In addition, if guarantees of non-repetition are granted to oppressed

\footnotetext{
${ }^{51}$ Saris and Lofts (n 29), 86.

52 See, for example; Rubio-Marín, ‘Transitional Societies' (n 38) 117; UN Human Rights Council (n 12), para. 62.

${ }^{53}$ Ibid, para 62.

54 Ibid, para. 65.

${ }^{55}$ See for example, Friedrich Rosenfeld, 'Collective Reparation for Victims of Armed Conflict,' (2010) 92(879) Intl Rev Red Cross 731. Sierra Leone's recommended reparations programme, which includes collective reparations aimed at the reconstruction and rehabilitation of the most war-affected regions. (King (n 48), 269). Ghana's proposed measure of reconstruction of local markets could be another example. National Reconciliation Commissions, 'National Reconciliation Commission Final Report,' Accra, 2004, Volume 1, Chapter 7; Ní Aoláin et al. (n 31).

${ }^{56}$ UN Human Rights Council (n 12), para. 65.
} 
groups who are then given collective forms of reparations in the aim of transforming society, this may pose a problem if other groups, such as certain groups of men who are not seen to be needing such reparations, are then given individual reparations including compensation. This would create injustice and, in fact, render victims who are also part of oppressed groups in some ways less visible than others, working to ensure they are only seen when part of a collective. ${ }^{57}$ Thus, while collective reparations through guarantees of non-repetition may be a promising area when it comes to challenging structural inequalities through reparations, these should not supplement individual reparations but should, rather, be granted in addition to the other reparations.

\section{Transformative Gender Reparations in the Courts: The Cotton Fields Judgment}

In this section I will further consider some of the different ways transformative reparations have been used, beginning by outlining the Cotton Fields judgment in the IACtHR which provides an example of the application of transformative reparations through guarantees of non-repetition. However, noting how gender justice must be intersectional, I will then go on, in the next section, to analyse this judgment and other granted reparations from an intersectional lens, calling for this lens to be applied to transformative reparations before moving on to consider the relationship between the right to reparations and the primary rights violations this secondary right responds to.

The 2009 judgment of González et al ("Cotton Field") v Mexico ${ }^{58}$ provided an attempt at understanding and applying a transformative gender model to reparations, working to unlink compensation and reparations. ${ }^{59}$ The case concerned two minors, both female, and a young woman. The victims were all abducted within the space of just over a month, subjected to sexual violence and killed by non-state actors. Their bodies were found in a cotton field in 2001 . The Court was presented

\footnotetext{
${ }^{57}$ Walker (n 32).

${ }^{58}$ González et al. ("Cotton Field") v. Mexico (n 41).

59 This need to unlink compensation and reparations is highlighted by Manjoo. (See, Manjoo, 'Introduction' (n 24), 1196).
} 
with evidence which showed a lack of due diligence on the part of the state in investigating the initial disappearances, noting, for example, that little was done to investigate before the bodies were found ${ }^{60}$ and that there were serious deficiencies in the autopsy reports. ${ }^{61}$ Thus, drawing on the Court's own past case law ${ }^{62}$ as well as the various international standards set around due diligence obligations, ${ }^{63}$ the state was deemed to have failed to have diligently investigated the case and thus failed to have properly prosecuted and punished the perpetrators. ${ }^{64}$ In addition, it was found that the state failed to treat the relatives of the deceased in a humane way. ${ }^{65}$ The Court concluded that the state violated the rights to life, freedom, personal integrity of victims, ${ }^{66}$ the right not to be discriminated against on the ground of sex and the right to access to justice and legal remedies under the American Convention. ${ }^{67}$ The Court also found that the state failed to apply due diligence to prevent, investigate and impose penalties for violence against women as well as failing in its duty to provide adequate legal responses to violence against women as required under the Inter-American Convention on the Prevention, Punishment and Eradication of Violence against Women. ${ }^{68}$ It is on this last point that the Court took a more transformative approach in that, here, the Court not only recognised the violations of the victims' rights in the case at hand but also worked to situate the case within the broader context of violence against women in the Ciudad Juárez region of Mexico. For example, the Court was presented with much evidence that the state had systematically failed to address multiple incidences of the killing or

\footnotetext{
${ }^{60}$ González et al. ("Cotton Field") v. Mexico (n 41), paras. 165-95.

${ }^{61}$ Ibid, paras. 217-221.

${ }^{62}$ Such as Maria da Penha v. Brazil, Case 12.051, Report No. 54/01, OEA/Ser.L/V/II.111 Doc. 20 rev. at 704 (2000) which the Court refers to in the Cotton Fields judgment in para. 255.

${ }^{63}$ Such as, for example, UN Committee on the Elimination of Discrimination Against Women (CEDAW), 'CEDAW General Recommendation No. 19: Violence Against Women,' UN Doc HRI/GEN/1/Rev.1, 11 ${ }^{\text {th }}$ Session 1992, para. 9; UN, 'Report of the Fourth World Conference on Women, Beijing,' Beijing Declaration and Platform for Action approved at the $16^{\circ}$ plenary session, A/CONF.177/20/Rev.1, 15 September 1995, para. 124 b; UN, 'Violence against women in the family: Report of the Special Rapporteur on violence against women, its causes and consequences, Radhika Coomaraswamy, submitted in accordance with Commission on Human Rights resolution 1995/85, UN Doc. E/CN.4/1999/68, 10 March 1999, para. 25.

${ }^{64}$ González et al. ("Cotton Field") v. Mexico (n 41), para. 389.

${ }^{65}$ Ibid, para. 440.

${ }^{66}$ Ibid, para. 389.

${ }^{67}$ Ibid, see, paras. 389 and 402.

${ }^{68}$ Organization of American States (OAS), 'Inter-American Convention on the Prevention, Punishment and eradication of Violence against Women,' 9 June 1994; González et al. ("Cotton Field") v. Mexico (n 41).
} 
disappearance of women in the Ciudad Juárez region since $1993,{ }^{69}$ concluding that the failure to investigate reports of missing women was common within the region. ${ }^{70}$ The Court, drawing on the evidence submitted to it, noted that these acts of violence were rooted in a broader systemic structure of gender-based violence ${ }^{71}$ drawing on the Commission's statement that there was an absence of state measures in regards to the disappearance and killing of victims. ${ }^{72}$ As highlighted by the Court, the state was aware of this ongoing issue, with multiple international monitoring mechanisms having called attention to the context. ${ }^{73}$ Despite this, it was shown that cases were not taken seriously due to gender discrimination. ${ }^{74}$ Overall, the Court concluded this created 'impunity. ${ }^{75}$

A series of reparations were mandated, including monetary compensation, symbolic redress and forms of guarantees of non-repetition. It is the latter which was particularly ground-breaking in this case, with the Court noting 'the context of structural discrimination' and the need for reparations to "change the situation, so that their effect is not only of restitution, but also of rectification. ${ }^{76}$ As noted above, guarantees of non-repetition is the area of reparations under which many feminists have pinned their hope for transformative reparations, the nature of such reparations requiring, inherently, a more structural understanding of the situation which must not be repeated. Under guarantees of nonrepetition, building on the case law before it on the due diligence requirements of the state, Mexico was ordered to improve the way cases of violence against women and disappearances of women would be dealt with, including the improvement of things such as: the state's ability to undertake criminal

\footnotetext{
${ }^{69}$ Ibid, paras. 147-150.

${ }^{70}$ Ibid, para. 195.

${ }^{71}$ Ibid, paras. $128-136$.

72 Ibid, para. 260.

${ }^{73}$ Ibid, para. 116. See, for example, UN, 'Report of the mission of the Special Rapporteur on Extrajudicial, Summary or Arbitrary Executions,' E/CN.4/2000/3, Add.3, 25 November 1999; UN, 'Report of the mission of the Special Rapporteur on the independence of judges and lawyers,' E/CN.4/2002/72/Add.1, 24 January 2002; UN, 'Report of the Committee of International Experts of the United Nations Office on Drugs and Crime, on the mission to Ciudad Juárez, Chihuahua, Mexico,' November 2003; European Parliament, 'Resolution on the murder of women (femicide) in Mexico and in Central America and the role of the European Union in fighting the phenomenon,' 2007/2025/(INI), 11 October 2007.

${ }^{74}$ González et al. ("Cotton Field") v. Mexico (n 41), para. 153.

${ }^{75}$ Ibid, paras. 158, 164.

${ }^{76}$ Ibid, para. 450.
} 
investigations in relation to violence against women in the region in question, ${ }^{77}$ the prohibiting of officials from discriminating based on gender ${ }^{78}$ and providing gender training for officials. ${ }^{79}$ Mexico was thus ordered to report to the Court on the implementation of these guarantees of non-repetition every year for a period of three years. ${ }^{80}$

The Cotton Fields case provides an example of how transformative gender-based reparations can and have been applied, focusing in on the potential of using guarantees of non-repetition. The judgment moves beyond considering the individual harms to the victims, noting the broader patriarchal structure within which these harms were situated, seeking to redress both the individual harms and challenge broader structural concerns. However, it is necessary, in order to understand whether these reparations really did have a transformative impact or not, to consider what happened following the judgment.

In 2013, the IACtHR issued a report with its findings in relation to compliance with the Cotton Fields judgment. ${ }^{81}$ While the Court found that the state had fulfilled many of the more commonly imposed forms of reparations, such as the payment of compensation, ${ }^{82}$ as shown below, while some of the more structurally transformative reparations were applied, many were also not fulfilled or were illapplied.

Thus, focusing on the more transformative reparations measures ordered, including the request for better procedures and training, one measure taken by the state in response to the Cotton Fields judgment was that the State of Chihuahua (where the Ciudad Juárez region is located), set up an Office of the Special Prosecutor for Assistance to Women Victims of Crime for Reasons of Gender. ${ }^{83}$ This

\footnotetext{
${ }^{77}$ Ibid, para. 497.

${ }^{78}$ Ibid, paras. 521-525.

${ }^{79}$ Ibid, paras. 521-543.

${ }^{80}$ Ibid, para. 18 of the Operative Paragraph.

${ }^{81}$ Inter-American Court of Human Rights, 'Resolución de la Corte Interamericana de Derechos Humanos: Caso González y Otras ("Campo Algodonero") Vs. Mexico, Supervisión de Cumplimiento de Sentencia,' 12 May 2013, http://www.corteidh.or.cr/docs/supervisiones/gonzalez_21_05_13.doc (accessed 26 June 2019).

${ }^{82}$ Ibid, para. 129 , pp. 37-38.

${ }^{83}$ Ibid, p. 4, para. 11. In Spanish: 'Fiscalía Especializada en Atención a Mujeres Víctimas del Delito por Razones de Género.'
} 
was set up, according to the state's own report, to promote prevention, investigation and prosecution and to ensure a greater focus on crimes against women. ${ }^{84}$ This measure also was taken to foster greater connections between different organisations within the state apparatus. ${ }^{85}$ In addition, the state reported that administrative procedures had been used across the state of Chihuahua to examine the work of several public sector workers, with sanctions being applied to thirty six people. ${ }^{86}$ However, reporting on the first and second state reports, the Commission expressed scepticism about the impact and reach of these sanctions, noting, for example, that it was not listed how many cases were considered. In addition, sanctions beyond administrative sanctions were not mentioned despite being, in the Commission's opinion, potentially necessary. ${ }^{87}$ While the state, in its third report, had claimed it was seeking to address some of these concerns, the Court concluded that more information was required to determine compliance. ${ }^{88}$ Accordingly, the judgment has not yet been fully complied with and remains under the supervision of the Court. The Court has confirmed this in its latest (at the time of writing) Annual Report for $2018 .^{89}$

In terms of the re-opening of the cases of the two minors and the young women victims in the Cotton Fields case and the calling for a gender and women's rights analysis of the case, the Commission found, in the first two reports on compliance, that a gender perspective had not been adequately applied to the cases. ${ }^{90}$ It seems, in response to these initial findings, that the state did then try to respond to the statements made by the Commission through the hiring of international experts to advise on the cases. ${ }^{91}$ While the Court's 2013 report notes the state's efforts, it also notes that not enough information had been provided in order to be able to analyse compliance properly. ${ }^{92}$ The Court

\footnotetext{
${ }^{84}$ Ibid, p. 4, para. 11.

${ }^{85}$ Ibid, p. 4, para. 11.

${ }^{86}$ Ibid, p. 10 , para. 34.

${ }^{87}$ Ibid, p. 11, para. 36 .

${ }^{88}$ Ibid, p. 11, para. 40.

${ }^{89}$ See, IACtHR, Annual Report 2018, http://www.corteidh.or.cr/tablas/informe2018/ingles.pdf (accessed July 2019 ) p. 85.

${ }^{90}$ Inter-American Court of Human Rights, 'Resolución de la Corte Interamericana de Derechos Humanos: Caso González y Otras (“Campo Algodonero”) Vs. Mexico, Supervisión de Cumplimiento de Sentencia,' 12 May 2013 (n 81), p. 8-9, paras. 24 and 25.

${ }^{91}$ Ibid, p. 8, para. 26.

${ }^{92}$ Ibid, p. 9, para. 30.
} 
thus determines that the reparation which required an obligation to investigate the facts of the case was, in 2013, 'pending compliance. ${ }^{93}$ At the time of writing, the judgment remained under supervision 'pending compliance. ${ }^{94}$

The state did report that protocols were reviewed in respect to cases of disappearance, sexual violence and the homicide of women. ${ }^{95}$ In addition, the Attorney General of Mexico drafted a report providing guidelines for the standardisation of investigations of crimes related to the disappearance of women, the crime of rape of women and the crime of homicide of women, ${ }^{96}$ this document replacing previous protocols. However, responding to the state's first and second report, the representatives of the victims argued that the incorporation of international standards into these documents was not reviewed by independent experts, stating also that civil society needed to be included further. ${ }^{97}$ While the representatives did not respond to the third report, it does seem, according to the Court's analysis, that, while further work is still needed, work was done to bring these guidelines in line with international standards, with the guidelines including elements such as: a list of determining factors which suggest a gender analysis is required; the outlining of and the requirement that staff have the knowledge of national and international human rights frameworks in relation to women's rights; and various other investigative and procedural guidelines. ${ }^{98}$ Despite these efforts however, it is clear that, given the ongoing issues in 2013 around the re-investigation of the original case and the lack of gender expertise and analysis being applied, that some of the outlined procedures and guidelines were not necessarily being followed in all instances.

\footnotetext{
${ }^{93}$ Ibid, p. 10, para. 31.

${ }^{94}$ IACtHR, Annual Report 2018 (n 89).

${ }^{95}$ Inter-American Court of Human Rights, 'Resolución de la Corte Interamericana de Derechos Humanos: Caso González y Otras (“Campo Algodonero”) Vs. Mexico, Supervisión de Cumplimiento de Sentencia,' 12 May 2013 (n 81, p. 19, para. 73).

${ }^{96}$ In Spanish the title is 'Lineamientos Generales para la estandarización de investigaciones de los delitos relacionados con desapariciones de mujeres, del delito de violación de mujeres y del delito de homicidio de mujeres por razones de género.' (Ibid, p. 19, para. 73).

${ }_{97}$ Ibid, p. 21, paras. 75-77.

${ }^{98}$ Ibid, p. 21, paras. $78-81$.
} 
Focusing on the implementation of education and training programmes for public officials in terms of implementing gender perspectives and overcoming stereotypes, the state reported that many such programmes were carried out at both the national and regional levels, targeting various levels of officials from state public official training to judicial training. ${ }^{99}$ The representatives of the victims, in their second state report response, argued that the information provided failed to outline who was targeted specifically by such training, failing also to list the number of courses provided, their duration and the contents of the training, calling these programmes 'isolated acts.' 100 The Court, however, in the 2013 report did find that sufficient education and training programmes had been put in place and that these seemed to be varied and widespread. The victims did not, however, respond to this report. ${ }^{101}$ In terms of education programmes for the general population of the State of Chihuahua, while the state noted that various activities had been put in place including radio programmes, workshops, awareness campaigns etc, ${ }^{102}$ the representatives, in their first and second follow-up reports, stated that the information provided by the state was too vague and that there was not enough evidence of a comprehensive programme, arguing that what the state had provided was evidence of isolated events. ${ }^{103}$ The state then provided further information in its third report, providing a more detailed outline of the multiple gender awareness programmes run, including preventative programmes and gender-based violence awareness training for several parties including the public and others such as school teachers. The state also gave some numbers, if not all, around how many people had been trained. ${ }^{104}$ While the representatives did not respond to the report, the Court found the state to have complied with this aspect of the reparations order. ${ }^{105}$ I was unable to find any studies on the impacts of such programmes.

\footnotetext{
${ }^{99}$ Ibid, pp. 29-31, para. 107.

${ }^{100}$ Ibid, p. 32, para. 108.

${ }^{101}$ Ibid, p. 23, paras. 110-111.

102 Ibid, p. 33, paras. 112 and 113.

${ }^{103}$ Ibid, p. 33, para. 114.

${ }^{104}$ Ibid, pp. 33-34, para. 117.

105 Ibid, p. 34, para. 119.
} 
As noted, the Cotton Fields case provides an example of how more transformative genderbased reparations can and have been applied. While some of these more transformative reparations were complied with by the state of Mexico in response to the Cotton Fields case, compliance was weaker when it came to these more transformative reparations. I have not been able to find evidence of the impacts of the measures taken by the state in terms of promoting gender analysis and challenging gender stereotypes within public officials and the general public in the region, though it is clear this research would prove invaluable if conducted. What does remain clear, however, is that despite the ground-breaking initiative taken in the Cotton Fields judgment, systemic violence against women in Mexico continues at an extremely high rate. ${ }^{106}$ This fact highlights how, even if transformative reparations are ordered, enforcement and the actual transformative impact of the reparations remains a core concern. In addition, even when such reparations are implemented, this does not mean that they will be implemented to the extent or effect which may initially have been hoped for.

Unfortunately, since the Cotton Fields judgment, the idea of transformative gender-just reparations has not been as widely taken up as hoped within human rights adjudication. It is evident, therefore, that transformative reparations remain an 'elusive' area ${ }^{107}$ and that the Cotton Fields judgment, despite being now a decade old, remains one of the core attempts to apply transformative gender-just reparations through the courts. Transformative gender-just reparations remain somewhat undefined in their scope and little applied. In addition, and as the next section will show, while the Cotton Fields judgment was key in highlighting the unequal gendered structures in which these violations were situated within, this focus on gender despite the clear presence of other factors of inequality, such as class, also leaves begging the question of which characteristics should be taken into account and which should not. While, in the Cotton Fields case, the more transformative reparations were applied mostly through merging shifts towards due diligence, non-discrimination and guarantees

\footnotetext{
106 Manjoo, 'Introduction' (n 24), 1199.

${ }^{107}$ Ibid, 1196.
} 
of non-repetition, such a model could be expanded beyond gender discrimination alone, as the next section will discuss.

E. Re-Thinking Transformative Gender Reparations: Intersectionality, Collective Reparations and the Limits of Human Rights

While the Cotton Fields judgment provides some jurisprudence on the ways gender justice can be sought through transformative reparations in the form of guarantees of non-repetition, there are many limitations to the judgment. In this section, I will analyse both the Cotton Fields judgment, as well as the broader literature on gender and transformative reparations through the lens of intersectionality, situating intersectionality as a core element of feminist and gender theory and as something which needs to be situated at the heart of transformative gender-just reparations. Thus, defining intersectionality as a core and necessary element for reparations to be able to realise their full transformative potential, this section will also note the need for further collective reparations before assessing the relationship between reparations, as a secondarily applied right, and the primary rights they respond to, before going on to analyse the limits of the law in being able to provide societal transformation.

Intersectionality as a term was coined by Crenshaw. ${ }^{108}$ Crenshaw’s work on discrimination law highlighted how seeing identities as distinct from one another in law, and therefore either seeing discrimination on the basis of race or on the basis of gender, meant that those discriminated against because of more than one characteristic, for example because they were a black woman, were not adequately seen by the law, this impacting on justice. ${ }^{109}$ While there have been some attempts to bring intersectionality into feminist work at the international level through the consideration of, for example,

\footnotetext{
108 While the term 'intersectionality' was dubbed by Crenshaw, there were multiple other feminist scholars who had the same arguments as Crenshaw prior to her. See for example, Cherríe Moraga and Gloria Anzaldúa (eds), This bridge Called my Back: Writings by radical Women of Color, (SUNY Press, $1^{\text {st }}$ edn 1981).

${ }^{109}$ Crenshaw (n 24).
} 
indigenous women's specific needs, or the needs of rural women, ${ }^{110}$ for the most part intersectionality does not fully inform feminist work in international law and the global order where the focus remains, largely, on including and representing women without account for which women are being represented, included and listened to. ${ }^{111}$

If, as Rubio-Marín states, the 'transformative potential' of reparations is to be found in 'the extent to which a reparations program has the capacity to subvert, instead of reinforce, preexisting structural inequalities, ${ }^{, 12}$ it is evidently necessary to ensure that all of those pe-existing structural inequalities are understood so that they can be challenged, including the structural inequalities which continue to be propped up by feminist projects in international law which centre a problematically monolithic or universal "women's" experience. ${ }^{113}$ It is important to note the multiple intersecting factors which cause oppression in order to be able to adequately redress harm and transform society. Transformative reparations literature has noted the need for further focus on intersecting forms of oppression to truly foster reparations which can challenge societal norms and inequalities. ${ }^{114}$ However, more in-depth analyses of what an intersectional frame of gender-just transformative reparations may

\footnotetext{
${ }^{110}$ UN Committee on the Elimination of Discrimination Against Women (CEDAW), 'CEDAW General Recommendation No. 13: Equal remuneration for work of equal value,' 1989.

${ }^{111}$ For more on the problematic focus of international law on the inclusion of women alone, the inclusion of some yet not all women and the lack of consideration of feminist methodologies see; Gina Heathcote, Feminist Dialogues on International Law: Successes, Tensions, Futures, (Oxford: Oxford University Press 2019); Hilary Charlesworth, Gina Heathcote and Emily Jones, 'Feminist Scholarship on International Law in the 1990s and Today: An Inter-Generational conversation,' (2019) 27(1) Feminist Legal Studies, 79; Ratna Kapur, Gender, Alterity and Human Rights: Freedom in a Fishbowl, (Cheltenham: Edward Elgar 2018); Gina Heathcote, 'Security Council Resolution 2242 on Women, Peace and Security: Progressive Gains or Dangerous Development?’ (2018) Global Society 374.

112 Ruth Rubio-Marín, 'Introduction: A Gender and Reparations Taxonomy,' in Ruth Rubio-Marín (ed), The Gender of Reparations: Unsettling Sexual Hierarchies while Redressing Human Rights Violations, (Cambridge: Cambridge University Press 2009) 1, 17.

${ }^{113}$ Heathcote (n 111); Kapur (n 111); Vasuki Nesiah, ‘The Ground Beneath Her Feet: “Third World” Feminisms,' (2003) 4(3) J Intl Women's Studies 30; Dianne Otto, 'The Gastronomics of TWAIL's Feminist Flavourings: Some Lunch-Time Offerings,' (2007) 9 Intl Community L Rev 345.

${ }^{114}$ For example, Rubio-Marín states that while the concern of her project is 'with gender hierarchies of power, this concept may apply to other forms of structural inequalities' and notes the need to consider sexual violence against men within the frame of analysis. (See, Rubio-Marín, 'Introduction' (n 112), 17. Mazurana and Carlson also explain the need to recognise the specific needs of girls and boys: Dyan Mazurana and Khristopher Carlson, 'Reparations as a Means for Recognizing and Addressing Crimes and Grave Rights Violations again Girls and Boys during Situations of Armed Conflict and under Authorities and Dictatorial Regimes,' in Ruth Rubio-Marín (ed), The Gender of Reparations (n 112) 162). In addition, Manjoo notes, while discussing the victory of the inclusion of sexual violence in many reparations programmes and reflecting on what is often left out, note that violations which are 'specifically related to systematic forms of discrimination, including based on sex, ethnicity or sexual orientation' are often excluded. (See; UN Human Rights Council (n 12), 44).
} 
include remain few, ${ }^{115}$ with such analyses tending to focus primarily on social, economic and political factors. ${ }^{116}$ In addition, such intersectional gender analyses have been little applied in practice, with many programmes still struggling to understand and often failing to even consider, let alone address, the ways in which women experience harms differently to men. ${ }^{117}$

An intersectional feminist lens challenges the core focus on the figure of "the woman" which is centred in much transformative reparations literature. As intersectional scholarship shows, there is no such thing as a monolithic woman's experience ${ }^{118}$ and there is a need to understand gendered experiences, not only through the lens of gender but also through multiple forms of oppression. This focus, indeed, must include a consideration of the economic, social and political factors as called for in existing literature, but must also move beyond such factors to consider multiple other groups who are rendered unequal, for example, through racism, ableism, class, caste, indigeneity, gender identity and sexuality, this list by no means being exhaustive. In addition, and in line with contemporary literature on intersectionality which notes the ever-shifting meanings given to identities across time and space, there is a need to bring other structurally oppressive forces, such as colonialism and capitalism, into the lens as well as to situate specific harms within a specific time and space. ${ }^{119}$ For reparations to be truly transformative, it is essential that all oppressive structures are seen in order that they can be transformed, allowing for more complex and holistic analyses of harm. While existing literature on transformative reparations has noted the need to challenge patriarchy in order to ensure non-discrimination, it has steered away from noting the need to challenge structures such as capitalism and colonialism and the need to note how the meaning of identities differ and shift across time and

\footnotetext{
115 One of the most in-depth analyses of the need for intersectional approaches can be found in the work of Ní Aoláin et al., who note the need to provide an intersectional analysis when applying reparations to address conflict related sexual violence. (See, Ní Aoláin et al. (n 31)).

${ }^{116}$ While some of this literature does note the need to consider identities other than gender, there is little analysis of how this could be put into place and on which identities should be included or excluded.

${ }^{117}$ For an overview of some of the ways in which gendered harms have been addressed or not, see, Ní Aoláin et al. (n 31 ). 118 See, Moraga and Anzaldúa (n 108); Crenshaw (n 24); Patricia J. Williams, The Alchemy of Race and Rights, (Boston: Harvard University Press 1992).

${ }^{119}$ For a discussion of understanding intersectionality beyond identity, considering multiple structural forces and the need to see intersectionality through time and space, see, Jasbir K. Puar, "I would rather be a cyborg than a goddess": BecomingIntersectional in Assemblage Theory,' (2012) 2(1) philoSOPHIA 49.
} 
space. This may be due to the tension with transformative reparations as situated within the human rights framework, transformative reparations largely being tethered to the primary right to nondiscrimination and thus being unable to move beyond the frame of human rights law and its understanding of harm. I will return to analysing this tension further in the last section of the chapter.

It is also key to note, drawing on queer and feminist scholarship, the instability of the category "woman" and the dangers of defining sex or gender in a binary manner. ${ }^{120}$ While many scholars in the field of human rights and transformative reparations still speak of men and women and their experiences of harm, defining gender as man/woman ensures that a whole host of subjects which do not neatly fit into this binary are inherently excluded from analysis in human rights work, including, for example, potentially trans, non-binary, intersex, lesbian, gay, bisexual and queer people, among others. ${ }^{121}$ Gender must be thought beyond the gender binary to ensure a wider array of subjects are included in all gender analysis, noting that the category of "woman" has never been stable and that gender has always been socially constructed. Thinking beyond the gender binary is necessary to adequately provide an intersectional analysis in this field so as to ensure that transformative reparations really can be used to transform all unequal and oppressive societal structures.

As noted, the Cotton Fields judgment provides a core example of why an intersectional analysis is necessary when seeking transformative reparations. While the more transformative reparations ordered in the case focus on gender alone, the judgment itself does note some of the other characteristics of the victims. Speaking generally, the Court notes that the women and girls murdered and disappeared in the region were, according to multiple national and international sources, all 'young women, including girls, women workers - especially those working the in maquilas - who are

\footnotetext{
120 Butler (n 24).

${ }^{121}$ Dianne Otto (ed), Queering International Law: possibilities, Alliances, Complicities, Risks, (London: Routledge 2017); Dianne Otto, 'Queering Gender [Identity] in International Law,' (2015) 33(4) Nordic J Hum Rts 299; Dianne Otto, 'Between Pleasure and Danger: Lesbian Human Rights,' (2014) 6 Eur Hum Rts L Rev 618; Dianne Otto, 'International human Rights Law: Towards Re-Thinking Sex/Gender Dualism,' in Margaret Davies and Vanessa E. Munro (eds), The Ashgate Research Companion to Feminist Legal Theory, (London: Routledge 2013) 197.
} 
underprivileged, students or migrants. ${ }^{122}$ In addition, speaking specifically about the victims in the case, the Court notes that all three were of 'humble origins' ${ }^{123}$ with the adult woman working in a maquila plant and the two minors being students, one of whom was also a domestic worker. ${ }^{124}$ In fact, the Court directly notes the relevance of these intersecting characteristics, drawing on evidence which highlighted the subsequent, in the Court's words, 'discrimination against a social class. ${ }^{\text {,25 }}$ Despite noting the relevance of the victims' intersectional characteristics, however, the Court chose to focus on gender discrimination alone when determining the violations and ordering reparations, the discrimination against these women as a social class getting left behind at this stage of the judgment.

The Cotton Fields case provides an example of the necessity of thinking transformative genderjust reparations intersectionally. This was clearly a case, not just of gender discrimination but also class discrimination, with the fact that these victims and the victims generally of the disappearances in the region all tended to be women from lower socio-economic backgrounds marking some women's lives as less important than both men's and other women's. If the reparations in the Cotton Fields judgment had also been read through an intersectional lens which also saw class, the reparations could potentially have reflected the need to address a wider range of discriminations including access to justice especially for poorer women in Mexico, as well as possibly the need to address poverty and specifically women's poverty either regionally or nationally. Such an approach may also have allowed economic and social rights violations to be made visible within the case. Such an understanding of reparations, however, seeking to address the wider context through which the violation is situated within, also requires a less individualised account of justice which, as opposed to seeking to redress the individual, seeks to address the individual as situated within the wider community. ${ }^{126}$

\footnotetext{
122 González et al. ("Cotton Field") v. Mexico (n 41), para. 123.

${ }^{123}$ Ibid, para. 168.

124 Ibid, paras. 165-7.

125 Ibid, para. 391.

${ }^{126}$ Feminist legal scholars have long called for more communal understandings of subjects as situated within the whole. See, Christine Chinkin et al., 'The Bozkurt Judgement: A Feminist Judgment of the Lotus Case' in Loveday Hodson and Troy Lavers (eds), Feminist Judgments in International Law, (Hart Publishing forthcoming 2019); Ngaire Naffine, 'The Body Bag,' in Ngaire Naffine and Rosemary Owens (eds), Sexing the Subject of Law, (North Ryde: LBC Information Services 1997) 79; Isabelle R. Gunning, 'Modernizing Customary International Law: The Challenge of Human Rights,'
} 
Collective reparations have, however, been applied more easily within reparations programmes set up following the end of a period of conflict. This has occurred for multiple reasons. One reason is the fact that these programmes are set up to deal with mass violations, the collective already being envisaged by the framing of the programme. In addition, the mass nature of the violations in these contexts makes it impossible to redress all people individually, this frame thus already fostering a more collective approach. ${ }^{127}$ In addition, such programmes often explicitly aim to provide more transformative visions of justice. This is, again, due to the nature of these programmes, many of which are partly set-up to ensure mass violations will never happen again. These goals inherently require that the harms and the causes of conflict are addressed explicitly to seek to promote the transition to sustainable peace. In addition, reparations programmes have the potential to be more flexible, applying reparations through administrative programmes as opposed to through judicial systems. These administrative programmes inherently have a broader remit than an individual court case. ${ }^{128}$ Further, reparations programmes, unlike judicially granted reparations, can, through collective reparations, help take the burden off the individual, including the burden of finding and giving evidence and the financial burden of bringing a claim. These differences have important gendered impacts in that women and many others may find it particularly difficult to access judicial systems. ${ }^{129}$ This seems to be why more holistic and transformative aiming systems of reparations, as discussed above, where reparations were granted such as small pensions, education opportunities and the provision of medical services, seeking to address community issues beyond the individual case at hand, have been applied much more in reparations programmes as opposed to in courts. Human rights courts could learn from such collective measures which may provide more radical transformations of society. At the same time, it is important

(1991) 31 Virginia J Intl L, 211; Jennifer Nedelsky, 'Reconceiving Autonomy: Sources, Thoughts and Possibilities' in Alan Hutchinson and Leslie Green (eds), Law and the Community: The End of Individualism? (Toronto: Carswell 1989), 219.

127 Saris and Lofts (n 29), 85.

${ }^{128}$ Rubio-Marín, 'Introduction' (n 112), 4.

${ }^{129}$ Ibid, 5. 
to ensure that the balance between the individual and the collective is thought through properly, as noted above.

An intersectional analysis of the Cotton Fields case may indeed have allowed further factors to be seen within the case and therefore for further transformative reparations to be applied accordingly. However, as noted above, there are clear limits to human rights courts when it comes to the granting and application of transformative reparations. Reparations are, in human rights courts, granted in response to the violation of a primary right and are granted on a case by case basis. This means that the framework of harm seen is already limited in scope by the very focus of the case at hand. ${ }^{130}$ Problems are thus posed by this model which inherently focuses on the individual or smaller community claim meaning that the broader picture is, by nature of the model, not made explicit. This is less of a problem in reparations programmes.

However, in both reparations programmes and cases brought before courts, there remain core limitations. One such limitation is the limited array of rights which can be claimed, this closing off what harms can be seen. For example, while a lot has been done to change rights to allow them to properly reflect the way women experience human rights violations, much is still left to do be done in this area. In addition, the consistent marginalisation of economic and social rights across the human rights system is a core problem in terms of the recognition and visibility of harms. ${ }^{131}$ In framing reparations around serious or gross violations of IHRL and IHL, it is often civil and political rights which are given priority, with economic and social rights often being framed as more aspirational and thus less enforceable. ${ }^{132}$ Economic and social rights, however, are essential if human rights are to be able to fully comprehend the harms people suffer. ${ }^{133}$ These rights are central if any intersectional gender model is to be applied; economic and social rights helping to make visible larger issues of

\footnotetext{
${ }^{130}$ Ibid, 4.

131 See; Philip Alston, 'Phantom Rights: The Systemic Marginalization of Economic and Social Rights,' (2016) Open Global Rights: https://www.openglobalrights.org/phantom-rights-systemic-marginalization-of-economic-and-socialrights/ (accessed 24 June 2019).

132 Rubio-Marín, 'Transitional Societies' (n 38), 78.

${ }^{133}$ Ní Aoláin et al. (n 31).
} 
inequality through, for example, gender, class and race, with some of the core harms women face occurring through economic and social rights violations. ${ }^{134}$ This marginalisation reflects some of the broader critiques of human rights law which I will return to in the next section of this chapter, including, as noted above, its limited focus on the individual and opposed to the collective (with economic and social rights often forcing a broadening out of scope), as well as the critique that human rights law currently overly reflects liberal and neoliberal interests, being unwilling to recognise the harms created by larger global oppressive structures such as capitalism.

In this section, I have noted that the right to reparation is a secondary right granted in response to a primary rights violation. I have also noted, however, that the harms conceptualised by and prioritised within the application of IHRL and IHL are limited and that these frameworks largely exclude intersectional understandings of harm. The next section will push this analysis further, questioning the possibility of being able to seek transformative gender justice through a secondarily applied rights framework alone.

\section{F. Transformative Justice Beyond Human Rights}

So far in this chapter, collective and intersectional approaches to reparations have been posed as ways to make reparations more transformative and gender-just. However, noting that the right to reparation is a secondarily applied right granted in response to the violation of a primary right, I have argued that transformative reparations will always be limited by the framing of the law, noting IHRL and IHL's marginalisation of economic and social rights and the limited focus on individual cases within human rights courts. In this section, I will push this analysis further, noting how, not only is the law unable to envisage the different harms which victims face but that the law, which is based upon a limited liberal framework, works to obstruct transformative visions of justice which lie beyond liberal legalism. This,

${ }^{134}$ Ibid, 96-7; Jurasz (n 31), 249. 
it is argued, is a core challenge for those seeking more transformative visions of justice, calling into question the utility of the law in such a project.

As feminist legal scholars have noted, the subject of international law is the liberal subject. He is thus male, white, heterosexual, able-bodied and middle class. ${ }^{135}$ This blueprint of subjectivity is then transposed to the legal subject in different areas of the law, whether this model is then applied to the individual through human rights, or the international legal personality of the corporation, or the framing of the legal personhood of the state; all of these models have been shown to be based on the same limited account of liberal subjectivity. ${ }^{136}$ In terms of human rights, Kapur has noted how the framing of human rights law around the liberal subject works to limit the ability of human rights to provide the freedom they promise, noting how:

... rights interventions occur within and against already established normative and material frameworks, namely, conventional racial, cultural, sexual and civilizational arrangements that inform both the ideology and apparatus of human rights. ${ }^{137}$

Human rights thus foster a system in which 'the entitled subject, the rights-seeking subject' is painted at the expense of erasing other freedom-seeking subjects. ${ }^{138}$

One example of the way in which human rights create a legitimate subject at the expense of the exclusion of the other can be seen in the debate over the veil. Many feminists have advocated for the banning of the veil, or what is more commonly though not always accurately described as the

\footnotetext{
${ }^{135}$ Rose Parfitt, 'Theorizing Recognition and International Personality,' in Anne Orford and Florian Hoffman (eds), The Oxford Handbook of the Theory of International Law, (Oxford: Oxford University Press 2016) 583; Anna Grear, "“Sexing the Matrix": embodiment, disembodiment and the law - towards the re-gendering of legal rationality,' in Jackie Jones, Anna Grear, Rachel Anne Fenton and Kim Stevenson (eds), Gender, Sexualities and Law, (London: Routledge 2011), 39; Naffine (n 126).

${ }^{136}$ On human rights, see; Kapur (n 111). On the corporate legal subject see; Anna Grear, 'Deconstructing Anthropos: A Critical Legal Reflection on 'Anthropocentric' Law and Anthropocene Humanity,' (2015) 26(3) Law and Critique 225. On the state, see; Karen Knop, 'Why Rethinking the Sovereign State is important for Women's International Human Rights Law,' in Rebecca J. Cook (ed.), Human Rights of Women, (Pennsylvania: Pennsylvania University Press 1994) 153; Yoriko Otomo, 'Endgame: feminist lawyers and the revolutionary body,' (2009) 31 Australian Feminist Law J 153; Hilary Charlesworth, 'The Sex of the State in International Law,' in Ngaire Naffine and Rosemary Owens (eds), Sexing the Subject of Law, (LBC Information Services, 1997) 251.

${ }^{137}$ Kapur (n 111), 15.

138 Ibid, 15.
} 
hijab, ${ }^{139}$ arguing that this piece of clothing is a symbol of women's oppression. Legal bans of the veil have thus followed. Cases questioning these bans have consequently been brought to the European Court of Human Rights (ECtHR) which has upheld these bans. ${ }^{140}$ While, as noted, the legal sanctioning against this piece of clothing is often articulated in terms of women's rights, this so-called feminist perspective ignores the fact that the veil has many meanings. While, indeed, the veil can be imposed as a form of oppression, the veil is also worn by many by choice, being a symbol of freedom (in multiple senses) for many. ${ }^{141}$ The veil cases and the wider debates on the veil and women's human rights exemplify how human rights, despite claiming to be promoting the universal human rights of all, are deeply political in terms of who is included and excluded. In this instance, a colonial gaze can clearly be seen in the argument that a particular piece of clothing inherently restrains a woman's freedom. ${ }^{142}$ 'Muslims,' Kapur thus notes, 'continue to be conceptualized as the embodiment of a threatening alterity, and always as incommensurable with the liberal values which are the substrate of human rights discourse. ${ }^{143}$ Unveiling therefore becomes a form of governance, ${ }^{144}$ excluding some from the universal humanity human rights claims to promote ${ }^{145}$ while forcing others to submit to be able to access the "freedom" human rights prescribes them.

It is clear from this example that human rights law, while claiming to provide a universal framework of freedom for all, is in fact a deeply political governance tool. The problem with human

\footnotetext{
${ }^{139}$ As Kapur states; 'I use the term 'veil' as a generic category that includes its various manifestations - the hijab, jilbab, abaya, niqab, burqa and chador - each version of the garment encoded with particular meaning for its adherents, proponents and opponents, and serving as both topos and target of national and regional socio-politics as well as global geo-politics.' (ibid, 120).

${ }^{140}$ See, Dakir v Belgium, Appl. No. 4619/12, 11 July 2017; Sahin v Turkey, Appl. no. 4474/98, 10 November 2005; S.A.S. $v$ France, Appl. no. 4835/11, 1 July 2014. For an analysis of these cases see Ratna Kapur, 'Alterity, gender Equality and the Veil' in Ratna Kapur, Gender, Alterity and Human Rights: Freedom in a Fishbowl, (Edward Elgar, 2018), 120-150.

${ }^{141}$ As Kapur states; 'I use the term 'veil' as a generic category that includes its various manifestations - the hijab, jilbab, abaya, niqab, burqa and chador - each version of the garment encoded with particular meaning for its adherents, proponents and opponents, and serving as both topos and target of national and regional socio-politics as well as global geo-politics.' (ibid, 120).

${ }^{142} \operatorname{Kapur}(\mathrm{n} 140)$.

${ }^{143}$ Kapur (n 111), 132.

144 Ibid, 130.

145 Of course, "humanity" has only ever been inscribed to some in international law. See, Kojo Koram, "Satan is Black" - Frantz Fanon's Juridio-Theology of Racialisation and Damnation,' (2017) Law, Culture and the Humanities, 1; Ayça Çubukçu, 'Thinking Against Humanity,' (2017) 5(2) London Rev Intl L, 251; Antony Anghie, 'Finding the Peripheries: sovereignty and colonialism in nineteenth century international law,' (1999) 40 Harvard Intl L J, 1.
} 
rights, however, is not only its use as a tool for governance but its universal claims. Human rights have become one of the most dominant accounts of freedom in the global order over the past century. In becoming such a powerful discourse however, as Kapur notes, human rights have worked to limit the very idea of what freedom is and can be to what is envisaged as freedom within human rights alone. Frames beyond this fishbowl of freedom are accordingly not only given less priority but are portrayed as unimaginable and erased. ${ }^{146}$ Accounts of freedom which are excluded by the human rights project, for example and following Kapur, include accounts of religious freedom and women's agency which lie beyond the liberal mindset, including the wearing of the veil by choice. ${ }^{147}$

However, the problems raised by human rights law and the wider aspirational project of human rights for what Kapur deems freedom but what could equally be called transformation, go beyond the concerns raised thus-far in that, not only does the human rights project promote a particular version of freedom at the exclusion of other versions and at the exclusion of certain subjects but, in fact, human rights, in side-lining alternative registers of freedom, are complicit in the upholding of oppressive structures. This can be seen in the veil examples given above, where human rights law has been used to uphold racist and colonial power dynamics. Another example can be seen when looking at the field of business and human rights. The business and human rights framework, while working to potentially temper the actions of corporations, also risks legitimating capitalism via its work with corporations. This allows corporations to be able to use the business and human rights frame to claim their "good" human rights credentials while exploiting people globally, from well-known examples such as the collapse of the Rana Plaza garment factory in Bangladesh in 2013 to the corporate violence of the everyday through, for example, paying people an un-liveable wage while making huge profits and claiming corporate social responsibility credentials. Businesses are, ultimately, set up to make a profit. While business and human rights frameworks may seek to negotiate between corporate capitalism and

\footnotetext{
146 Kapur (n 111).

${ }^{147}$ Ibid, 120.
} 
social justice, these projects ultimately have incommensurable goals, with the business and human rights frame both moderating and legitimating capitalism. ${ }^{148}$

Returning to transformative justice, it is clear that the human rights project itself may pose a problem for those seeking transformative justice and that this poses a problem for the transformative reparations project. Walker has made a similar argument, arguing that the transformative element of transformative reparations is too vague and aspirational. Walker thus argues that this is a fundamental flaw in the transformative reparations project, stating that such reparations are politically unreal and, in fact, risk displacing reparative justice and the benefits of the individual victim-centred approach. Walker thus argues that, while transformation may be a goal of transformative justice, this cannot be a goal of reparations. ${ }^{149}$

As I have shown in this section, while, I agree with Walker that transformative reparations face several limitations, I do not think that this project risks marginalising the individual reparative model. This is due to the fact that individual and collective reparations can be granted alongside one another. In addition, I do not see the transformative justice project at the heat of transformative reparations as politically unreal in and of itself. Rather, I have noted that the limitation is to be found in the human rights project. The framing of human rights is what renders more radical visions of transformative justice politically unreal, excluding alternative visions of equality, freedom and justice through promoting human rights as the only political reality. While indeed, as Walker argues, broader transitional justice mechanisms may be better suited to fulfilling transformative aims than reparations alone ${ }^{150}$ the limits of the human rights project remain. The human rights project is a governance project which, while promoting itself as the universal theory of freedom for all, actively limits how transformative justice or, in Kapur's words, freedom, can be envisaged. The human rights project will

\footnotetext{
148 See; Grietje Baars, The Corporation, Law and Capitalism: A Radical Perspective on the Role of Law in the Global Political Economy, (Leiden and Boston: Brill 2019).

${ }^{149}$ Walker (n 32).

${ }^{150}$ Ibid.
} 
always include some people and ideas while excluding others. ${ }^{151}$ However, this conundrum does not automatically mean that the human rights project should be completely abandoned. Kapur, for example, while critiquing the human rights project, does not reject the importance of this project in terms of power or as a means for granting legibility to some otherwise disenfranchised people. Rather, Kapur asks her reader to see human rights as the governance project it is, noting the usefulness of human rights in some instances while asking the reader to retain a knowledge of its limitations. ${ }^{152}$

While my aim has been, in this chapter, to seek to understand how transformative reparations can challenge multiple structures of oppression, the critical human rights literature outlined above problematises that possibility by highlighting the limitations of working within IHRL and IHL and thus the broader frame within which reparations sits. These neo/liberal legal frameworks, as noted, only see certain structures of oppression, being unable to challenge the harms caused by the human rights project itself, with this project at times upholding and legitimising many oppressive structures including capitalism, racism and colonialism. This evidentially leaves the transformative gender-just reparations project in tension. On the one hand, transformative reparations could and have had, in some cases, a positive impact on people's lives. However, reparations can only respond to primary rights violations. These primary rights, however, are unable to comprehend the many oppressive power structures which gender-just transformative reparations seek to address. For transformative justice to really be able to be transformative, there is a need to challenge the limitations of the human rights project which reparations work within. In the meantime, however, noting that the human rights project remains a powerful albeit problematic tool, it seems that while it must be recognised that transformative reparations can only have a limited transformative impact, work which seeks to push this area further towards more transformative frames remains key.

\footnotetext{
${ }^{151}$ Kapur (n 111), 132.

152 Ibid.
} 


\section{G. Conclusion}

In this chapter I have noted the need for reparations to seek to address the broader structures of inequality and discrimination which foster human rights violations, noting the often-unsatisfactory outcomes of compensation and restitution which risk returning the person in question back to a situation of discrimination and inequality and thus a position in which their human rights are still being violated. As noted, much feminist work has identified guarantees of non-repetition as a key area through which more transformative reparations may be applied. Feminists working on transformative reparations have argued, in this vein, for more collective reparations such as educational and housing programmes. While it is clear that collective reparations need to be further perused, a greater focus on economic and social harms within reparations is also required. In addition, I have also argued for the necessity of the application of an intersectional gender analysis to transformative reparations. Intersectional analyses allow for multiple, intersecting oppressive power structures to be seen and thus potentially addressed by transformative reparations, this being essential to any vision of transformative justice.

However, the grating of reparations is tied to repairing violations found under IHRL and IHL. Reparations are secondarily applied rights, granted in response to the violation of a primary right meaning that their transformative potential will always be limited by the framing and finding of a violation of a primary right. However, this primary rights framework, I have argued, is framed around a limited account of freedom which inherently only includes some subjects and ideas at the exclusion of others. In addition, as shown through the examples of the banning of the veil and the business and human rights field, human rights are not only a tool for governance but, rather, at times human rights uphold and legitimate oppressive power structures such as colonialism and capitalism. This begs the question of, how can transformative reparations transform society when they are part of system which is implicit in oppression and inequality? 
Feminists working in international law have long found themselves caught between resistance and compliance; caught between using international law as a tool to change women's immediate circumstances while wishing to challenge the problematic and oppressive structures of international law itself. ${ }^{153}$ However, these two approaches should not be seen as inherently opposed to one another. For example, critical feminist scholars who analyse the problematic structures of international law and human rights by no means operate entirely outside the frame of the law, working often to propose legal solutions while retaining a perspective which is mindful of the limits of the law. ${ }^{154}$ Methods of both resistance and compliance need to be and can be held together at the same time, embracing the contradictions which arise accordingly. What thus becomes clear in thinking through these multiple levels of analysis and all the paradoxes and contradictions which arise, therefore, is that there is no one solution. Human rights remain a core and powerful tool of liberation for some. While the human rights project has serious limitations and while engaging with human rights risks legitimising exclusions, using human rights to seek justice should not be abandoned despite these contradictions. However, there is a need to 'let go' of human rights as the only project which can provide freedom and emancipation ${ }^{155}$ and see human rights for what they are - a powerful governance tool which includes and excludes, legitimates and delegitimates. Engaging with human rights and thus with the field of transformative reparations, seeking to push these projects towards more transformative or radical aims, therefore, remains a centrally important project, yet such projects should not be held up as the only means through which emancipation can and should be sought. There is a need, following the words of

\footnotetext{
${ }^{153}$ I have taken the terminology 'resistance and compliance' from a key text within feminist approaches to international law which discusses the tension between these two modes. See, Sari Kouvo and Zoe Pearson (eds), Feminist Perspectives on Contemporary International Law: Between Resistance and Compliance? (Oxford: Hart 2014).

${ }^{154}$ See, for example, Heathcote (n 111); Kapur, (n 111); Otto (ed), 'Queering International Law' (n 121); Karen Engle, 'The grip of Sexual Violence: Reading United Nations Security Council Resolutions on Human Security,' in Gina Heathcote and Dianne Otto (eds), Rethinking Peacekeeping, Gender Equality and Collective Security, (Basingstoke: Palgrave Macmillan 2014) 23; Vasuki Nesiah, 'Feminism as Counter-Terrorism: the Seduction of Power,' in Margaret L. Satterthwaite el al. (eds), Gender, National Security, and Counter-Terrorism, (Routledge, 2013) 127; Nesiah (n 113).

155 Kapur (n 111), 3.
} 
Haraway, to "stay with the trouble, ${ }^{, 56}$ to note the contradictions and paradoxes and hold them together in the aim of challenging oppressive power structures at multiple levels.

The field of transformative reparations remains somewhat ill-defined and there is much room yet for manoeuvre. As I have argued, thinking through collective reparations further and pushing for the stronger recognition of economic and social harms while also centring intersectionality, could provide some means through which to develop this field further. At the same time, I have argued that bringing a critical feminist approach to the transformative reparations debate is essential. There is a need to think through and hold close the limits of reparations in being able to transform society, noting the problematic human rights governance structure in which they are situated within. Transformation must thus be demanded from within while retaining an understanding that transformation will always be limited when sought within the frame of the law.

${ }^{156}$ Donna Haraway, Staying with the Trouble: Making Kin in the Chthulucene, (Durham and London: Duke University Press 2016). 